\title{
Efeito de IBA e de rizobactéria no enraizamento de miniestacas de Acácia negra
}

Angela Cristina Ikeda, Paulo César Flôres Júnior, Vanessa Ishibashi, Andressa Vasconcelos Flôres, Antonio Rioyei Higa, Katia Christina Zuffellato-Ribas

Universidade Federal do Paraná - UFPR. E-mail: aikeda@ufpr.br

\section{Resumo}

A acácia negra é uma espécie florestal de expressiva importância econômica na região sul do Brasil e a investigação de métodos de propagação vegetativa para constituição de florestas clonais é de grande valia para aumento da produtividade florestal. O objetivo deste trabalho foi avaliar a ação de promotores de enraizamento na miniestaquia de Acacia mearnsii como alternativa para a propagação vegetativa da espécie. 0 experimento foi conduzido no mês de julho/2018 (estação de inverno) com uma testemunha, duas concentrações de ácido indol butírico - IBA (2000 e $4000 \mathrm{mg} \mathrm{L}^{-1}$ ) e duas concentrações do inoculante AzoTotal ${ }^{\circledR}(100 \%$ e $50 \%)$ que contem a bactéria Azospirillum brasilense. Para os tratamentos com IBA, as bases das miniestacas permaneceram imersas em solução hidroalcoólica 1:1 durante 10 segundos e para o inoculante durante 15 minutos. $O$ experimento foi conduzido em casa de vegetação e após 45 dias avaliouse a porcentagem de miniestacas enraizadas, número de raízes por miniestaca, comprimento das três maiores raízes por miniestaca, porcentagem de miniestacas com calos, porcentagem de sobrevivência das miniestacas, porcentagem de miniestacas com brotação e porcentagem de miniestacas que mantiveram os folíolos. Houve diferença significativa entre os tratamentos para miniestacas enraizadas, número de raízes por miniestaca e comprimento das três maiores raízes, não ocorrendo para as demais variáveis analisadas. A utilização de IBA em $4000 \mathrm{mg} \mathrm{L}^{-1}$ mostrou-se mais eficaz $(63,7 \%$ de enraizamento) para o processo de propagação vegetativa da espécie.

Palavras-chave: Acacia mearnsii; ácido indol butírico; Azospirillum brasilense; inoculante.

\section{Effect of IBA and rhizobacterium in rooting of Black wattle minicuttings}

\begin{abstract}
Black wattle is a forest species of great economic importance in the southern of Brazil. Researches for vegetative propagation methods to constitute clonal forests are effective to increase forest productivity. The goal of this work was to evaluate the action of compounds to promote rooting in minicuttings of Acacia mearnsii as an alternative to vegetative propagation to the species. We conducted the experiment in July/2018 (winter season) with one negative control, two concentrations of indole butyric acid - IBA (2000 and $4000 \mathrm{mg} \mathrm{L}^{-1}$ ) and two concentrations of AzoTotal ${ }^{\mathrm{TM}}$ (100\% e 50\%), an inoculant containing Azospirillum brasilense bacterium. In the IBA treatments, the base of minicuttings remained immersed in hydroalcoholic solution 1:1 for 10 seconds and for the inoculant treatments during 15 minutes. The experiment took place in a greenhouse and after 45 days, we evaluated the percentage of rooted minicutting; number of roots per minicutting; length of the three largest roots per minicutting; percentage of minicuttings with calluses; percentage of minicuttings survival; percentage of minicutting with budding and percentage of minicutting that kept the leaflets. There was significant difference between treatments considering rooted minicuttings, number of roots by minicutting, length of the three largest roots by minicutting and we did not observe differences to the other variables analyzed. The use of IBA at $4000 \mathrm{mg} \mathrm{L}^{-1}(63.7 \%$ of rooted minicuttings) was more effective for the vegetative propagation process in this species.
\end{abstract}

Keywords: Acacia mearnsii; Azospirillum brasilense; indole butyric acid; inoculant. 


\section{Introduction}

Acacia mearnsii De Wild. is known as black wattle, it belongs to Fabaceae family, its origin is Australian and it was introduced in Brazil in 1918 with the first commercial plantations developed since 1928. Nowadays, there is an area of approximately 90 thousands of hectares concentrated in the state of Rio Grande do Sul, Brazil. Black wattle provides multiple products as biomass to produce pulp and pellets; wood for firewood and charcoal and bark for tannin extraction (AGEFLOR, 2017).

Black wattle plantation is commonly from seminal seedlings, resulting in forests with high genetic variability and variation in productivity (DISARZ; MARTINS-CORDER, 2009). Therefore, the use of clonal forests provides homogeneity in plantation and it is an option of considerable increasing of productivity. However, the lack of adequate techniques has been limiting the use of vegetative propagation methods in large-scale to black wattle.

Consequently, it is essential for productivity gains in forest species to understand about vegetative propagation techniques that are associated to the use of substances that promote root increasing. In addition to the hormonal balance, rooting process has influence of physiological conditions, matrix age, juvenility of the collected material, luminosity, humidity, temperature and type of minicutting (XAVIER et al., 2013).

Some forest species can present limiting conditions to seedling production via vegetative propagation. Species classified as relatively easy to root respond well to the rooting process when submitted to treatments containing synthetic auxins, while the others need co-factors that help in rooting, once they do not produce them endogenously (HARTMANN et al., 2011).

Auxins are chemical compounds capable to induce cell elongation and plants naturally produce them as indole acetic acid (IAA). They are associated to several process like geotropism, phototropism, cell differentiation, apical dominance, initiation of adventitial and lateral roots, cell division stimulation, stem and root elongation. Indole butyric acid (IBA) is a synthetic auxin that enables an increase in rooting process of juvenile minicuttings depending on its concentration and its interaction with different genetic materials (TEALE et al., 2006; TAIZ et al., 2017).
Administrate IBA in adequate concentration is an alternative to obtain higher rooting percentage in black wattle in the vegetative propagation process by cutting (ENGEL et al., 2017; LIMA et al., 2018; STUEPP et al., 2018). However, there were not many reports of techniques for vegetative propagation for this species, and so, the use of inoculants, products holding beneficial microorganisms for plants, is an alternative to improve rooting process in forest species.

One inoculant contains both growthpromoting and nitrogen-fixing bacteria. Concerning that, researchers take place to investigate rhizobacteria, once they can induce changes in the hormonal balance increasing the rhizogenesis (LARRABURU; LLORENTE, 2015). One important and known plant-growth promoter bacterium is Azospirillum brasilense, which has the ability of IAA production (SPAEPEN et al., 2013; DALLA ROSA et al., 2018).

The IAA is naturally synthetized in vegetal tissues those have high rate of growth. It has the tryptophan as precursor and can act increasing length and number of root hair, expanding absorption of water and nutrients besides promotes tolerance against low humidity condition in soil (CASSÁN et al., 2014). Thus, using the inoculant containing $A$. brasilense it is possible to increase the percentage of in vitro or ex vitro rooting, reduce the requirements of exogenous auxin and then, decrease the costs of vegetative propagation process (LARRABURU; LLORENTE, 2015; DALLA ROSA et al., 2018).

Since black wattle responds to rooting in high concentrations of IBA, the use of bioproducts carrying rhizobacteria that produce auxin possibly helps to develop roots in its minicuttings. Therefore, as an alternative to vegetative propagation of black wattle, the objective of this study was to evaluate the action of the plant regulator IBA and the inoculant AzoTotal $^{\mathrm{TM}}$ containing the rhizobacterium $A$. brasilense as rooting promoters in A. mearnsii.

\section{Material and Methods}

The minicuttings were prepared using four clones of black wattle from a mini-clonal hedge placed in the forest nursery located at the Laboratory of Forest Biotechnology, Federal University of Parana, Curitiba, Brazil. The miniclonal hedge was stablished in 2014 with black wattle clones provided by TANAC Company and 
the same number of minicuttings from each clone was collected to constitute a mix of minicuttings.

We prepared semi hardwood minicuttings $12 \mathrm{~cm}$ long with average diameter of $2.54 \mathrm{~mm}$, straight cut at the top and bevel cut at the base, keeping two leaflets in apical portion with half reduced area. Minicuttings were phytosanitary treated with $0.5 \%$ sodium hypochlorite during 10 minutes followed by washing under running water during five minutes.

The five treatments established were one negative control; two applications of indole butyric acid (IBA P. A., Merck ${ }^{\text {TM}}$ ) in hydroalcoholic solution $50 \%$ at $2000 \mathrm{mg} \mathrm{L}^{-1}$ and $4000 \mathrm{mg} \mathrm{L}^{-1}$; and two applications of AzoTotal ${ }^{\mathrm{TM}}$ inoculant at $100 \%$ and $50 \%$. For the IBA treatments, the bases of the minicuttings remained immersed in the solution for 10 seconds and for the inoculant containing $A$. brasilense for 15 minutes.

We placed the minicuttings in $55 \mathrm{~cm}^{3}$ tubes containing vermiculite as substrate, in an experimental design completely randomized with four replications totaling 80 minicuttings per treatment and 400 minicuttings in the whole experiment. The minicuttings remained in greenhouse with controlled temperature $\left(25^{\circ} \mathrm{C} \pm\right.$ $\left.5^{\circ} \mathrm{C}\right)$ and humidity $(90 \% \pm 5 \%)$ during 45 days.

After this period in greenhouse we evaluated rooted minicutting (RM); number of roots per minicutting (NRM); length of the three largest roots per minicutting (LRM); percentage of minicuttings with calluses (MC); percentage of minicuttings survival (MS); percentage of minicutting with budding (MB) and percentage of minicutting that kept the leaflets (ML).

Normality of data was tested by Kolmogorov-Smirnov $(P>0.05)$ and homogeneity of residual variances by Levene test $(P>0.05)$. In order to meet with these assumptions, data from rooted minicuttings (RM) and number of roots per minicutting (NRM) and length of the three largest roots per minicutting (LRM) were transformed using square root.

Data of minicuttings survival (MS) did not meet the analysis of variance assumptions and thus, Kruskal-Wallis $(P<0.05)$ non-parametric test was used. For the data of other variables ANOVA and Duncan test $(P<0.05)$ were used to compare the means. All statistical tests were performed using the statistical software SPSS ${ }^{\circledR}$ (IBM SPSS, 2017).

\section{Results and Discussion}

At 45 days after setting the experiment, there was no minicuttings with calluses (MC). The mean of minicutting survival (MS) was $96.7 \%$ and no difference was detected among the treatments $(P>0.05)$ (Figure 1 ).

Figure 1. Percentage of minicuttings survival of black wattle at 45 days.

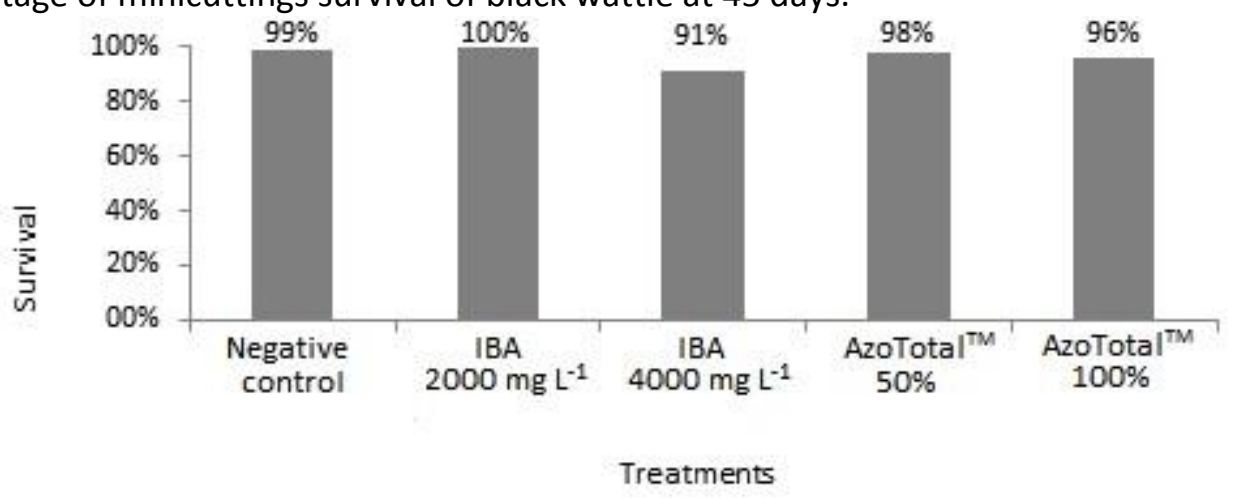

Percentage of minicutting survival is an important indicative of adequate management in the system of clonal seedling production, especially in the stages of establishment in miniclonal hedge and greenhouse. Low survival rates relate to some factors such as, water management in greenhouse, lignification stage of minicuttings, biotic diseases and even due to treatments application (XAVIER et al., 2013).
According to data observed for survival, the management in the system of clonal seedling production of black wattle has been efficient, once the variables that could interfere negatively in the development of rooting process of minicuttings are under control.

Turgidity loss in minicuttings may be a problem due to the management system, because the cellular turgidity in vegetal tissues is 
necessary to keep cell division and consequently, tissue growth and survival (BATISTA et al., 2014). The increasing of plant growth regulators concentration also can influence minicuttings survival, when they inhibit the rhizogenic process in the plant. Faganello et al. (2015) and Mantovani et al. (2017) worked with Cordia trichotoma and Peltophorum dubium, respectively, and both observed a decrease in minicutting survival coupled up with the increase of IBA concentration.

Martins et al. (2015) tested two concentrations of IBA and IAA for rooting in Campomanesia adamantium and found that the IAA regulator was more effective in herbaceous cuttings, but woody cuttings respond better for rooting and survival in low concentration of IBA. It depends on the period of collect, because factors like temperature can influence in rooting process and nutrients availability. As we worked with semi hardwood minicuttings, the nutritional storage probably helped in minicuttings survival and endogenous auxin interacted with the exogenous one (IBA in solution and IAA from bacteria) for rooting process.

Variance analysis revealed significant differences among treatments for rooted minicuttings $(P<0.05)$, number of roots per minicutting $(P<0.05)$ and length of the three largest roots per minicutting $(P<0.05)$. The same did not occur to percentage of minicutting with budding $(P<0.05)$ and percentage of minicutting that kept the leaflets $(P>0.05)$ (Figure 2$)$.

Figure 2. Evaluation of Black wattle minicuttings after 45 days. A. Negative control; B. IBA $2000 \mathrm{mg} \mathrm{L}^{-1}$; C. IBA $4000 \mathrm{mg} \mathrm{L}^{-1} ;$ D. AzoTotal ${ }^{\mathrm{TM}} 100 \%$ and E. AzoTotal ${ }^{\mathrm{TM}} 50 \%$.

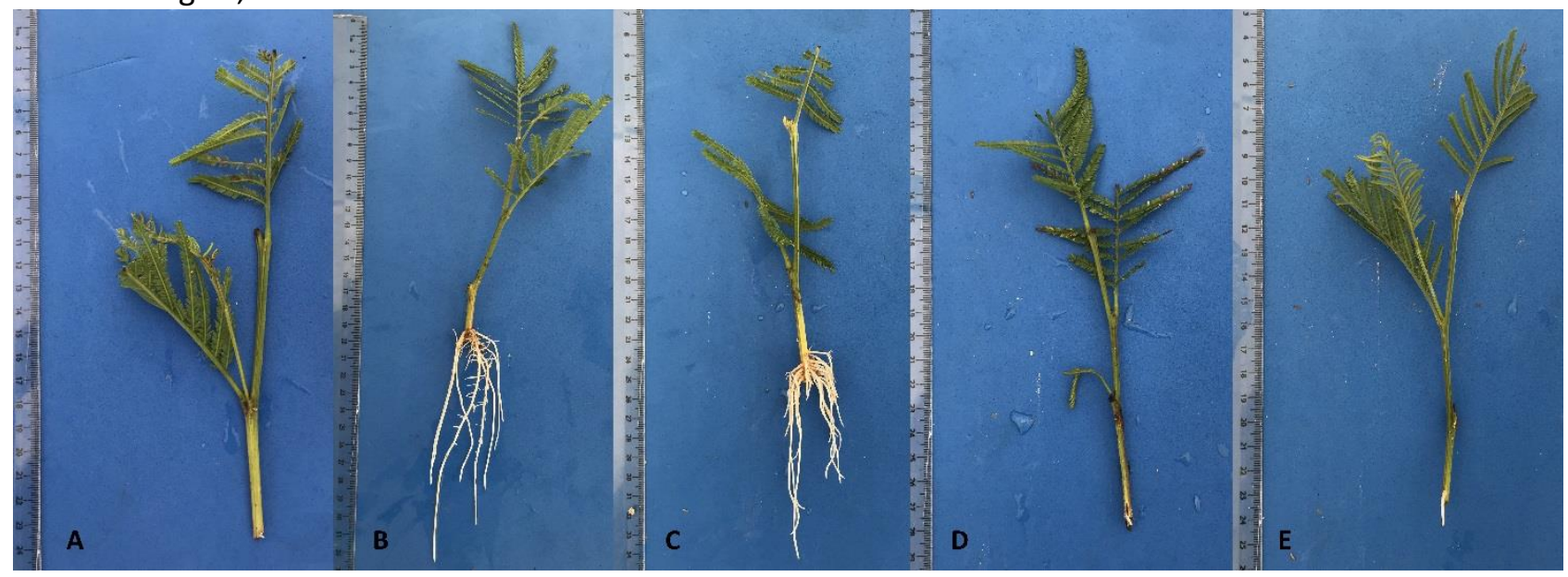

Additionally, environmental conditions at the time of cutting concerning different seasons, and the genetic potential for rooting as well as matrix physiological conditions influence the ability of minicutting to root (LEANDRO; YUYAMA, 2008; LATOH et al., 2018). Variation in clonal response is common in vegetative propagation of black wattle as observed by Engel et al. (2017) evaluating rooted minicuttings, number of roots per minicutting and length of the three largest roots. The authors used three clones of black wattle to test different concentrations of IBA and found $58.3 \%, 75.0 \%$ and $91.7 \%$ of rooting at $4000 \mathrm{mg} \mathrm{L}^{-1}$. This variation shows that the genotype influences on minicutting rooting process. It is important to emphasize that in our study, the experimental design did not aim a response by genotype, just for the species.

Therefore, it was used a mix containing four clones of black wattle minicuttings. The high coefficients of experimental variation (CV\%) for RM, NRM, LRM and MB can be attribute to variation among parcels/plots because of differences concerning genetic material, once minicuttings were made from clones coming from the same mini-clonal hedge (Table 1). 
Table 1. Analysis of variance and coefficient of experimental variation (CV\%) for rooted minicuttings (RM), number of roots per minicuttings (NRM), length of the three largest roots per minicutting (LRM), minicuttings with budding (MB), minicuttings that kept leaflets $(\mathrm{ML})$ in black wattle.

\begin{tabular}{cclllll}
\hline \multirow{2}{*}{ Variation Factor } & \multirow{2}{*}{ Degrees of Freedom } & \multicolumn{5}{c}{ Mean square } \\
& & RM & NRM & LRM & MB & ML \\
\hline Treatment & 4 & $29.78^{*}$ & $2.99^{*}$ & $4.47^{*}$ & $259.75^{\text {ns }}$ & $119.82^{\text {ns }}$ \\
Residue & 15 & 3.87 & 0.15 & 0.15 & 546.87 & 111.90 \\
CV\% & & 36.10 & 20.80 & 27.50 & 34.90 & 11.60 \\
\hline
\end{tabular}

${ }^{\text {ns }}$ not significant and $*$ significant at $5 \%$ probability.

The IBA treatments provided the highest percentages of rooted minicuttings and did not differ from each other, what demonstrates that semi hardwood minicuttings of $A$. mearnsii are relatively easy to root. Negative control presented $17.6 \%$, AzoTotal ${ }^{\mathrm{TM}}$ application approximately $15 \%$ and IBA treatments were three times higher (63.7\%) for $4000 \mathrm{mg} \mathrm{L}^{-1}$ and four times superior (80\%) for $2000 \mathrm{mg} \mathrm{L}^{-1}$ compared to the other treatments (Table 2).

Table 2. Mean of treatments in black wattle minicuttings. Rooted minicuttings (RM), number of roots per minicutting (NRM), length of the three largest roots per minicutting (LRM), minicuttings with buddings $(\mathrm{MB})$, minicuttings that kept the leaflets (ML).

\begin{tabular}{llllll}
\hline Treatment & RM (\%) & NRM & LRM (cm) & MB (\%) & ML (\%) \\
\hline IBA 2000 mg L & $80.0^{\mathrm{a}}$ & $5.98^{\mathrm{b}}$ & $7.14^{\mathrm{a}}$ & $75.9^{\mathrm{a}}$ & $89.9^{\mathrm{a}}$ \\
IBA 4000 mg L & $63.7^{\mathrm{a}}$ & $10.04^{\mathrm{a}}$ & $5.88^{\mathrm{a}}$ & $73.8^{\mathrm{a}}$ & $97.5^{\mathrm{a}}$ \\
Negative control $^{\mathrm{a}}$ & $17.6^{\mathrm{b}}$ & $1.18^{\mathrm{c}}$ & $0.34^{\mathrm{b}}$ & $58.2^{\mathrm{a}}$ & $82.4^{\mathrm{a}}$ \\
AzoTotal $^{\text {TM }} 100 \%$ & $15.5^{\mathrm{b}}$ & $1.25^{\mathrm{c}}$ & $0.36^{\mathrm{b}}$ & $59.3^{\mathrm{a}}$ & $92.4^{\mathrm{a}}$ \\
AzoTotal $^{\text {TM }} 50 \%$ & $15.2^{\mathrm{b}}$ & $1.18^{\mathrm{c}}$ & $0.98^{\mathrm{b}}$ & $68.0^{\mathrm{a}}$ & $92.5^{\mathrm{a}}$ \\
\hline Mean & 38.4 & 3.93 & 2.94 & 67.0 & 90.9 \\
\hline
\end{tabular}

Means followed by the same letter in the column do not differ statistically from one to another by the test of Duncan at $5 \%$ probability.

Although we consider semi hardwood minicuttings of black wattle relatively easy to root, we observe that minicuttings used in our experiment needed auxin administration to develop the roots. When the endogenous auxin is not sufficient, it is important to supplement them to promote a hormonal balance making possible minicutting rooting (FRAGOSO et al., 2017).

Minicuttings that received the inoculant AzoTotal ${ }^{\mathrm{TM}}$ containing $A$. brasilense showed similar performance to the negative control considering RM, NRM and LRM. The averages of number of roots per minicuttings varied from 1.18 to 10.04 and we observed the best result in the higher concentration of IBA. The lowest root lengths occurred in the negative control and applications of AzoTotal ${ }^{\mathrm{TM}}$ treatments.

Due to auxin production, the effects of inoculating rhizobacteria of Azospirillum spp. genus refer mainly to growth or modification in morphology of roots. The inoculation increases the number of lateral roots and/or roots hair what expands the surface of absorption of nutrients and water, as one of the main factor of plant growth (SPAEPEN et al., 2013; CASSÁN et al., 2014). In our work, the low efficiency of AzoTotal $^{\text {TM }}$ inoculation for roots development is possibly because the application method that provided insufficient exposure time of minicuttings to the inoculant containing the bacterium.

Mariosa et al. (2017) worked with semi hardwood cuttings of Olea europaea L. testing isolates of rhizobacteria and they did not find differences in number of roots per minicutting applying $A$. brasilense type-strain, even during 60 minutes of cutting immersion in the cultured medium as way of inoculation. In addition, they did not find correlation between IAA production by bacteria in vitro and root formation in the olive cuttings. 
In other study also with olive, Dalla Rosa et al. (2018) applied AzoTotal ${ }^{\mathrm{TM}}$ in the substrate, but did not observed superior results for rooting. The highest percentage of rooted cuttings was with IBA $4000 \mathrm{mg} \mathrm{L}^{-1}$ added to AzoTotal ${ }^{\mathrm{TM}}$ containing $A$. brasilense. Working with Arabidopsis Cohen et al. (2015) observed that inoculation with $A$. brasilense enhanced plant biomass and root surface besides reduced the harmful effects on plants submitted to water restriction. Then, the protective and plant growth effects are combined as a result of this bacterium inoculation and therefore, mutual IBA application and bacteria inoculation can be an alternative to induce, respectively, rhizogenesis and growth of root surface as improving number and/or length of the roots.

It is possible that the period of contact between the inoculant and the minicutting base was not sufficient for the adherence of bacteria. On the other hand, bacteria could not act in IAA supply for root emission, but they could act in increase the surface of the already formed roots. Accordingly, we recommend further studies with different IBA concentrations combined with AzoTotal $^{\mathrm{TM}}$, besides tests concerning different forms of inoculant application. One alternative is do not immerse the minicuttings inside the inoculum, but put the inoculum containing the bacteria in adequate concentration in contact to the base of the minicuttings to maintain lasting interaction between bacteria and the minicutting.

In our work, AzoTotal ${ }^{T M}$ treatments were not efficient to characterize qualitative and quantitatively the effect of rooting per minicutting, given the low potential of rooting and number and length of roots formed. The average of number of roots per minicutting in negative control and AzoTotal ${ }^{\mathrm{TM}}$ treatments was about 1.2. In IBA treatments, the average of NRM to $4000 \mathrm{mg} \mathrm{L}^{-1}$ concentration was $40 \%$ higher than $2000 \mathrm{mg} \mathrm{L}^{-1}$ and almost $90 \%$ higher than the other treatments.

In the treatments with better rooting performance, NRM and LRM presented respectively, 5.98 and $7.14 \mathrm{~cm}$ to $2000 \mathrm{mg} \mathrm{L}^{-1}$, and 10.04 and $5.88 \mathrm{~cm}$ to $4000 \mathrm{mg} \mathrm{L}^{-1}$. These data indicate that with half of IBA concentration the root growth was higher while the number of roots per minicutting was lower. In a study with the same species, Engel et al. (2017) found similar results; in the lowest concentration of IBA, the average of LRM was superior applying 4000

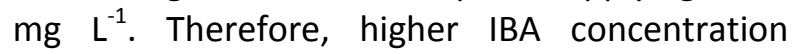

supplies a greater number of roots, but lower concentration of this regulator provides larger roots length (Figure 2, letter $B$ and $C$ ).

It is important to note that NRM and LRM are essential for clonal forestry practice. The reason is that it is necessary that the number and the length of roots be efficient to the architecture of root system, once smaller roots may not support the seedling development in field. Consequently, studies developed with black wattle show that the use of IBA is essential in clonal process via minicutting and prospect that the use of inoculants may optimize the action of this vegetal regulator to increase the root system in the plant.

Sousa et al. (2013) observed that the use of auxins in adequate concentrations stimulate adventitious roots emission and enhance rates of rooting. In organogenesis, high concentrations of auxins and low of cytokinins benefit the formation of roots, while the opposite helps in aerial development, as the cytokinin inhibits root constitution (NAKHOODA et al., 2012). The auxins and cytokinins imbalance can stimulate buddings formation, and in our study, this variable (MB) did not present difference among the treatments.

In general, high percentage of buddings is associated to lower rates of rooting. Physiologically, it may indicate that most of reserves used for rooting process translocated to form the buddings (BISCHOFF et al., 2017). At this time, it can explain part of the low rooting percentages observed in our study. In addition, the percentage of minicuttings that kept the leaflets did not presented difference, and so, the maintenance of original leaflets was not a limiting factor for rhizogenesis.

We conclude that the best developer of rooting in minicuttings of black wattle is the plant growth regulator IBA. This, at concentration of $4000 \mathrm{mg} \mathrm{L}^{-1}$ promotes a higher number of roots formation. The application of AzoTotal ${ }^{\mathrm{TM}}$ containing the bacterium $A$. brasilense does not have effect on minicuttings rooting when applied by immersion during 15 minutes. Therefore, we recommend further studies concerning use of IBA couple up with the inoculant holding rhizobacteria. In addition, we suggest supplementary tests for different concentrations and ways of application of these products in minicuttings of black wattle.

\section{Acknowledgments}

We thank to CAPES (Coordenação de 
Aperfeiçoamento de Pessoal de Nível Superior) and CNPq (Conselho Nacional de Desenvolvimento Científico e Tecnológico) for the financial support. To the company TANAC for the availability of black wattle materials and to Total Biotecnologia for the availability of AzoTotal ${ }^{\mathrm{TM}}$ inoculant for the development of this work.

\section{References}

AGEFLOR. A indústria de base florestal no Rio Grande do Sul - Ano Base 2016. Porto Alegre, 2017.

BATISTA, A.F.; SANTOS, G.A.; QUEVEDO, F.F.; ASSIS, T.F. Influence of basal cutting system of minicutings in clonal propagation of Eucalyptus urophylla x Eucalyptus globulus subsp. Maidenii hybrid. Revista Árvore, v.38, n.6, p.1115-1122, $2014 . \quad$ http://dx.doi.org/10.1590/S0100$\underline{67622014000600016}$

BISCHOFF, A.M.; VENDRAMIM, D.W.; GOMES, E.N.; ZUFFELLATO RIBAS, K.C.; ENGEL, M.L.; MAGGIONI, R.A. Rooting of black sage cuttings according to different indole butyric acid concentrations and number of leaves. Revista de Ciências Agroveterinárias, v.16, n.1, p.41-47, 2017.

https://doi.org/10.5965/223811711612017041

CASSÁN, F.; VANDERLEYDEN, J.; SPAEPEN, S. Physiological and agronomical aspects of phytohormone production by model plant bacteria-promoting rhizobacteria (PGPR) belonging to the genus Azospirillum. Journal of Plant Growth Regulation, v.33, n.2, p.440-459, 2014. https://doi.org/10.1007/s00344-013-9362$\underline{4}$

COHEN, A.C.; BOTTINI, R.; PONTIN, M.; BERLI, F.J.; MORENO, D.; BOCCANLANDRO, H.; TRAVAGLIA, C.N.; PICCOLI, P.N. Azospirillum brasilense ameliorates the response of Arabidopsis thaliana to drought mainly via enhancement of ABA levels. Physiologia Plantarum, n.153, p.79-90, 2015. https://doi.org/10.1111/ppl.12221

DALLA ROSA, D.; VILLA, F.; DA SILVA, D.F.; CORBARI, F. Rooting of semihardwood cuttings of olive: indolbutyric acid, calcium and Azospirillum brasilense. Comunicata Scientiae, v.9, n.1, p.3440, 2018. https://doi.org/10.14295/cs.v9i1.977
DISARZ, R.; MARTINS CORDER, M.P. Multiplication of axillary shoots in Acacia mearnsii de wild. Under different culture medium. Revista Árvore, v.33, n.4, p.599-606, $2009 . \quad$ http://dx.doi.org/10.1590/S0100$\underline{67622009000400002}$

ENGEL, M.L.; HIGA, A.R.; ALCANTARA, G.D.; FLÔRES JUNIOR JR, P.C.; SOARES, I.D. Minicuttings rooting of different Acacia mearnsii De Wildeman clons with aplication of IBA. Revista Espacios, v.38, n.23, p.8-19, 2017.

FAGANELLO, L.R.; DRANSKI, J.A.L.; MALAVASI, U.C.; MALAVASI, M.M. Effects of the indolbutiric and naphthaleneacetic acids on the rooting of Cordia trichotoma (Vell.) Arrab. ex Steud. Semiwoody cuttings. Ciência Florestal, v.25, n.4, 2015. http://dx.doi.org/10.5902/1980509820584

FRAGOSO, R.O.; STUEPP, C.A.; RICKLI, H.C.; ZUFFELLATO-RIBAS, K.C.; KOEHLER, H.S. Maximum efficiency concentration of indole butyric acid in promoting the rooting of Japanese Flowering Cherry. Ciência Rural, v.47, n.1, 2017. http://dx.doi.org/10.1590/0103-8478cr20150894

HARTMANN, H.T.; KESTER, D.E.; DAVIS JR., F. T. GENEVE, R.L. Plant propagation: principles e practices. Boston: Prentice Hall, 2011.

IBM. SPSS Statistics for Windows, Version 25.0. Armonk NY: IBM Corp., 2017.

LARRABURU, E.E.; LLORENTE, B.E. Azospirillum brasilense enhances in vitro rhizogenesis of Handroanthus impetiginosus (pink lapacho) in different culture media. Annals of forest science, v.72, n.2, p.219-229, 2015. https://dx.doi.org/10.1007/s13595-014-0418-9

LATOH, L.P.; DALLAGRANA, J.F.; PORTES, D.C.; MAGGIONI, R. de A.; ZUFFELLATO-RIBAS, K.C. Vegetative propagation via stem cutting of species of the genus Tibouchina spp. in the seasons. Revista Eletrônica Científica da UERGS, v.4, n.1, p.17-41, 2018. http://dx.doi.org/10.21674/2448-0479.41.17-41

LEANDRO, R.C.; YUYAMA, K. Rooting of cutia nut cuttings with indolbutiric acid. Acta Amazônica, v.38, n.4, p.597-502, 2008. http://dx.doi.org/10.1590/S0044$\underline{59672008000400001}$ 
LIMA, C.C.; OHASHI, S.T.; SILVEIRA, A.S. Effect of concentration of different IBA and origins geographical in parica stakes of rooting. Ciência Florestal, v.28, n.3, p.1282-1292, 2018. http://dx.doi.org/10.5902/1980509833380

MANTOVANI, N.; ROVEDA, M.; TRES, L.; FORTES, F.O.; GRANDO, M.F. Cultivation of canafistula (Peltophorum dubium) in mini-clonal hedge and propagation by mini-cuttings. Ciência Florestal, v.27, n.1, p.225-236, 2017. http://dx.doi.org/10.5902/1980509826461

MARTINS, W.A.; MANTELLI, M.; SANTOS, S.C.; NETTO, A.P.C.; PINTO, F. Cutting and concentration of plant regulators on rooting of Campomanesia adamantium. Revista de Ciências Agrárias, v.38, n.1, p.58-64, 2015.

MARIOSA, T.N.; MELLONI, E.G.P.; MELLONI, R.; FERREIRA, G.M.R.; SOUZA, S.M.P.; SILVA, L.F.O. Rhizobacteria and development of seedlings from semi-hardwood cuttings of olive (Olea europaea L.). Amazonian Journal of Agricultural and Environmental Sciences, v.60, n.4, p.302-306, 2017. http://dx.doi.org/10.4322/rca.2447

NAKHOODA, M.; WATT, M.P.; MYCOCK, D. The properties and interaction of auxins and citokynins influence rooting of shoot cultures of Eucalyptus. African Journal of Biotechnology, v.11, p.16568-16578, 2012. http://dx.doi.org/10.5897/AJB12.1523

SOUSA, C.M.; BUSQUET, R.N.; VASCONCELLOS, M.A.S.; MIRANDA, R.M. Effects of auxin and misting on the rooting of herbaceous and hardwood cuttings from the fig tree. Revista Ciência Agronômica, v.44, n.2, p.334-338, 2013. http://dx.doi.org/10.1590/S1806-

$\underline{66902013000200016}$

SPAEPEN, S.; BOSSUYT, S.; ENGELEN, K.; MARCHAL, K.; VANDERLEYDEN, J. Phenotypical and molecular responses of Arabidopsis thaliana roots as a result of inoculation with the auxinproducing bacterium Azospirillum brasilense. New Phytologist, v.201, n.3, p.850-861, 2014. https://doi.org/10.1111/nph.12590

STUEPP, C.A.; WENDLING, I.; XAVIER, A.; ZUFFELLATO-RIBAS, K.C. Vegetative propagation and application of clonal forestry in Brazilian native tree species. Pesquisa agropecuária brasileira, v.53, n.9, p.985-1002, 2018. https://doi.org/10.1590/S0100-

$\underline{204 \times 2018000900002}$

TEALE, W.D.; PAPONOV, I.A.; PALME, K. Auxin in action: signalling, transport and the control of plant growth and development. Nature Reviews Molecular Cell Biology, v.7, n.11, p.847-859, 2006. https://doi.org/10.1038/nrm2020

TAIZ, L.; ZEIGER, E.; MOLLER, I.M.; MURPHY, A. Fisiologia e desenvolvimento vegetal. Porto Alegre: Artmed, 2017.

XAVIER, A.; WENDLING, I.; SILVA, R. L. DA. Silvicultura clonal: princípios e técnicas. Viçosa: UFV, 2013. 